
\title{
28 Research Square \\ In Vitro Callus Culture of Dianthus Chinensis L. for Assessment of Flavonoid Related Gene Expression Profile
}

\section{R. Sreelekshmi}

University of Kerala

Elenjikkal A Siril ( $\square$ easiril@yahoo.com )

University of Kerala https://orcid.org/0000-0002-4956-8428

\section{Research Article}

Keywords: China pink, In vitro flavonoid production, Friable callus, 2,4- D, Chalcone synthase

Posted Date: March 17th, 2021

DOl: https://doi.org/10.21203/rs.3.rs-320486/v1

License: (c) (1) This work is licensed under a Creative Commons Attribution 4.0 International License.

Read Full License 


\section{Abstract}

Dianthus chinensis L. is an edible, ornamental herb used to prepare the Dianthi Herba, a Chinese traditional rejuvenating medicine. Owing to the rapid proliferation of callus tissues, in vitro production of flavonoids has their own specific importance. Callus cultures raised followed by auxin directed biosynthesis of flavonoid through related transcript profile were carried out. Murashige and Skoog (MS) medium fortified with 2,4- Dichlorophenoxy acetic acid (2,4-D) or picloram induced formation of friable callus from internode derived cultures of $D$. chinensis. Culture medium containing 2,4- D $(10 \mu \mathrm{M})$ produced the highest flavonoid content, $4.44 \mathrm{mg}$ quercetin equivalent per gram (QE g ${ }^{-1}$ ) under incubation in continuous dark condition, while maximum dry weight yield $(0.38 \mathrm{~g} /$ culture) was obtained from $10 \mu \mathrm{M}$ 2,4- D under $16 \mathrm{~h}$ light / $8 \mathrm{~h}$ dark condition ( $50 \mu \mathrm{mol} \mathrm{m} \mathrm{m}^{-2} \mathrm{~s}^{-1}$ irradiance) at 60 days of incubation. The callus raised in light condition in $10 \mu \mathrm{M} 2,4-\mathrm{D}$ selected to analyze flavonoid related gene expression profile viz., chalcone synthase (CHS), chalcone isomerase $(\mathrm{CHI})$, flavanone-3-hydroxylase $(\mathrm{F} 3 \mathrm{H})$, and flavonol synthase (FLS) at specific time intervals. The transcript abundance of $\mathrm{CHS}, \mathrm{F} 3 \mathrm{H}$, or FLS gene was higher at 60 days old callus cultures and reaching 11.59, 48.31, and 114.63-fold relative expression than that of initial callus tissues respectively. These understandings are critical for the regulation of targeted phytochemicals as well as their wide exploitation in the field of biological research.

\section{Key Message}

We have established an efficient callus culture system for flavonoid accumulation in Dianthus chinensis, and 2,4- D had a significant effect on flavonoid related gene expression on specific time intervals.

\section{Introduction}

Dianthus chinensis (China pink) is one of the widely known ornamental plants, also valued as medicinal herb in the traditional Chinese system of medicine. In the herbal formulation, 'Dianthi Herba' (Qu-Mai), major component is the areal part of $D$. chinensis and the drug is used as diuretic or anti-inflammatory agent (Jiangsu New Medical College 1977; Lopez-Exposito et al. 2011) specifically, to treat urinary infection, carcinoma, gonorrhea, and carbuncles (Oshima et al. 1984; Wang et al. 1998; Raman and Park 2015). The plant extract has apoptotic, anti-oxidant, anti-cancerous, and anti-inflammatory activities (Nishiumi et al. 2011; Nho et al. 2012; Shin et al. 2013; Oh et al. 2018). A literature survey on different Dianthus species revealed the presence of important bioactive compounds belongs to flavonoids, terpenoids, saponins, and phenols are responsible for its pharmacological activities (Galeotti et al. 2008b; Ma et al. 2009; Luo et al. 2011; Obmann et al. 2011). Among these, flavonoid groups are highly valued secondary metabolite in plant kingdom for its action in antioxidant, anti-inflammatory, chemo-preventive, antitumor, hepato-protective, anti-microbial, estrogenic, against neurodegenerative, cardiovascular, and other age-related diseases (Kumar et al. 2013; Skrzypczak-Pietraszek et al. 2018). So far, a variety of flavonoids like apigenin, kaemp-ferol, and quercetin derivatives have been identified from Dianthus species (Curir et al. 2003; Baloetti et al. 2008a and b). 
In recent years, the plant tissue culture technique has become an effective tool to achieve enhanced production of secondary metabolites, especially when resources in the natural stands for the extraction of metabolite is facing shortage or scarcity of specific bioactive compounds due to increasing the demand (Zhou et al. 2020). Studies on factors involved in vitro production of secondary metabolites and biosynthesis increasingly received attention (Lucho et al. 2018; Duan et al. 2019; Biswasa et al. 2020; Kumar et al. 2020). Dianthus chinensis maintained as an ornamental plant in several parts of the world. However, exploitation of this plant as an herbal drug in the form of 'Diantha Herba' and other novel formulations restricted due to low availability of dried plant biomass and seasonal nature, which necessitate exploration of alternative method for enhancing the metabolite production. The callus cultures often employed as model to produce metabolite due to proliferation coupled with fast growth of undifferentiated cells. The callus cultures also enable investigations on genetic behavior of tissue specific effective metabolite production. Moreover, there are many reports supporting the effective production of flavonoids via callus culture in different plant species (Masoumian et al. 2011; Wang et al. 2013; Kumar et al. 2014; Zheng et al. 2018; Kabita et al. 2019). The efficiency of $D$. chinensis or $D$. caryophyllus on callus induction has been reported in various cultivars to entertain organogenesis (Jethwani and Kothari 1996; Kantia and Kothari 2002; Pareek et al. 2004; Fu et al. 2008; Teixeira da Silva 2014; Maurya et al. 2019). However, the in vitro metabolite production or genes responsible for compound accumulation in $D$. chinensis cultures have not been researched so far.

Flavonoid biosynthesis mechanism is often the best studied pathways among plant secondary metabolites both through biochemical and molecular explorations (Koes et al. 2005; Hichri et al. 2011). In phenylpropanoid pathway, phenylalanine ammonia lyase (PAL) being the first entering enzyme towards flavonoid production (Ververidis et al. 2007). In plants, the structural as well as regulatory genes have been involved in the regulation of flavonoid biosynthesis (Schijlen et al. 2004). In spite of regulatory genes, the structural genes of flavonoid biosynthesis have shown a positive relation towards flavonoid accumulation (Stracke et al. 2009; Azuma et al. 2012; Jiang et al. 2013). The enzymes coding structural genes including, chalcone synthase (CHS), chalcone isomerase ( $\mathrm{CHI})$, flavanone-3-hydroxylase ( $\mathrm{F} 3 \mathrm{H})$, and flavonol synthase (FLS) are responsible for flavones and flavonol production (Jaakola et al. 2004; Nakatsuka et al. 2012). The regulation of these structural genes has considered as primary regulators for diverse flavonoid groups under various conditions (Lepiniec et al. 2006; Hichri et al. 2011).

Since last three decades, flavonoid biosynthetic pathways in plants received due attention in plant science research. The metabolic engineering process aimed to flourish various aspects such as; model plants (to explain the general biosynthetic pathways), floricultural plants (to produce different ornamental plants), plants for increased tolerance to pathogens (engineering of phytoalexin), and crop plants for flavonoid enhancement (Tohge et al. 2017; Nabavi et al. 2020). As an important floricultural plant, $D$. chinensis is known for its extremely diverse color pigmentation and are responsible for production of varied flavonoids and anthocyanin derivatives. In view of this the highly proliferated in vitro callus cultures can be treated as tool to dissect and manipulate the genetic route of flavonoid production. Many folds enhanced production of metabolite can be targeted by over expression of key genes in the metabolic pathways. The over expression of $\mathrm{CHI}$ gene has effectively enhanced flavonoid yield in hairy 
root culture of Glycyrrhiza glabra (Zhang et al. 2009) and Scutellaria baicalensis (Park et al. 2011). Li et al. (2006) states that, CHI gene transferred hairy root cultures of Saussurea involuerata have been expressed an enhanced production of flavonoids in contrast to its wild type hairy roots. Moreover, down regulation of flavonoids has reported by silencing of $\mathrm{CHS}$ gene in transgenic hairy roots of Medicago truncatula (Wasson et al. 2006). These understandings are critical for the regulation of in vitro production flavonoids. The relationship between in vitro cell line growth and metabolite production has been partially elucidated (Palacio et al. 2012; Loredo-Carrillo et al. 2013). To our knowledge, the influence of PGRs on flavonoid production and gene expression studies in callus cultures of $D$. chinensis has not been investigated. Herein we conducted a research on the establishment of an effective protocol for in vitro callus induction of $D$. chinensis with a focus on flavonoid accumulation in terms of biosynthesis related $\mathrm{CHS}, \mathrm{CHI}, \mathrm{F} 3 \mathrm{H}$, and FLS transcript profile.

\section{Materials And Methods}

\section{In vitro callus induction}

Dianthus chinensis L. (cultivar; Floral lace light Pink) was collected from District Horticultural Nursery, Thiruvananthapuram, Kerala state, S. India was used as the experimental material. The excised internode $(\sim 1 \mathrm{~cm})$ or leaf segments $\left(\sim 0.5 \mathrm{~cm}^{2}\right)$ of healthy shoots was selected, surface sterilized (Sreelekshmi and Siril 2021) and trimmed sterilant exposed cut portion under sterile condition. To study the effect of auxins on callus induction, the excised explants were inserted in to $15 \mathrm{ml}$ Murashige and Skoog (MS) medium containing 3\% sucrose, $0.7 \%$ agar (Sisco Research Laboratories, Mumbai, India), and various concentrations $(0,2.5$, or $5 \mu \mathrm{M})$ of 2,4-dichlorophenoxyacetic acid (2,4-D), a-naphthaleneacetic acid (NAA), 4-Aaino-3,5,6-trichloro-2-pyridinecarboxylic acid (picloram), indole-3-acetic acid (IAA), or indole-3butyric acid (IBA) (Sigma-Aldrich, Bangalore, India). The cultures were maintained at $25 \pm 2{ }^{\circ} \mathrm{C}$ with $55 \pm 5$ $\%$ relative humidity, and $16 \mathrm{~h}$ photoperiod in cool white fluorescent tubes ( $40 \mathrm{~W}$, Philips, India) with 50 $\mu \mathrm{mol} \mathrm{m} \mathrm{m}^{-2} \mathrm{~s}^{-1}$ irradiance. After 40 days of inoculation, callus morphology, percentage of callus, and fresh weight accumulation $(\mathrm{g} /$ culture) were duly recorded.

The callus ( 200 $\mathrm{mg}$ ) raised from intermodal explants on MS medium supplemented with $5 \mu \mathrm{M} 2,4-\mathrm{D}$ were transferred after 40 days to culture flask containing $30 \mathrm{ml}$ MS medium supplemented with varying concentrations $(0,2.5,5,10$, or $15 \mu \mathrm{M})$ of $2,4-\mathrm{D}$, and were incubated under photoperiod of $16 \mathrm{~h}$ light (50 $\mu \mathrm{mol} \mathrm{m} \mathrm{m}^{-2} \mathrm{~s}^{-1}$ ) or complete dark condition. MS medium without any auxins were treated as control. All the parameters like callus fresh weight (FW), dry weight (DW), and total flavonoid content were determined on every 20 days intervals up to 80 days.

The collected callus samples were dried in a hot air oven at $60{ }^{\circ} \mathrm{C}$ (Remi Scientific Instruments, Secunderabad, India). The grind callus sample was then subjected to extraction in $80 \%$ methanol (Wang et al. 2015), and quantified total flavonoid (TF) by aluminium chloride method (Chang et al. 2002) using a UV-Visible spectrophotometer (Model: UV-1700, Shimadzu Instruments, Tokyo, Japan) at $415 \mathrm{~nm}$. The TF was calculated based on standard calibration curve $(0-50 \mu \mathrm{g} / \mathrm{mL}, \mathrm{R} 2=0.99)$, using quercetin 
(Sigma-Aldrich, St. Louis, US). The TF was expressed as mg quercetin equivalent (QE) ${ }^{-1} \mathrm{~g}$ of DW. To assess the stability of flavonoid production, the callus $(\sim 200 \mathrm{mg})$ raised in $10 \mu \mathrm{M} 2,4-\mathrm{D}$ media were subcultured to MS medium containing $10 \mu \mathrm{M} 2,4-\mathrm{D}$ and were incubated at a photoperiod of $16 \mathrm{~h}$ light/ 8 $\mathrm{h}$ dark and the subcultures practice continued 4 times at every 60 days interval, and at the end of incubation period flavonoid yield was determined.

\section{Callus growth index and water accumulation}

The growth capacity of callus in terms of growth index (GI) was determined as the ratio of the accumulated and the initial biomass. The callus Growth index of callus raised in medium containing 2,4$\mathrm{D}(10 \mu \mathrm{M})$ at every 10 days interval was calculated by the following formula; $\mathrm{GI}=\mathrm{Wf}-\mathrm{Wi} / \mathrm{Wi}$. Where, $\mathrm{GI}$ represents growth index, Wf and Wi represents the final and initial fresh weight of callus (GodoyHernandez and Vazquez-Flota, 2006).

In vitro cultures of $D$. chinensis are highly vulnerable to varying degrees of hyperhydricity (Sreelekshmi and Siril 2020; Sreelekshmi et al. 2021a and b), thus callus mass accumulates high proportion of water leading to increment in fresh weight. The water accumulation of cultures raised in medium containing 2,4- $\mathrm{D}(10 \mu \mathrm{M})$ was determined at every 10 days interval using the formula; Callus moisture content $(\%)=$ Fresh weight - Dry weight×100/ Dry weight.

\section{RNA isolation and CDNA synthesis}

The efficiency of metabolite production specific to expression of flavonoid synthesis gene was measured by isolating the callus biomass raised in medium containing $10 \mu \mathrm{M} 2,4-\mathrm{D}$ at $1,20,40,60$, or 80 days intervals. Three biological replicates for each culture were randomly selected, ground in liquid nitrogen, and sample (100 mg) from each, pooled for RNA isolation using trizol reagent (Ambion by Life Technologies, Invitrogen, Carlsbad, USA) method (Simms et al. 1993). The concentration and integrity of RNA sample was quantified by NANO DROP ONE (Thermo Scientific, USA) and agarose gel (1.6\%; SRL, Mumbai, India) electrophoresis. Five hundred nanogram of RNA were converted in to CDNA using Primer Script ${ }^{\mathrm{TM}}{ }_{1}$ st strand cDNA Synthesis Kit AB-1453/B (Thermo Scientific, USA) according to the manufacturer's instructions. The $20 \mu \mathrm{l}$ final reaction mixture was incubated at $42^{\circ} \mathrm{C}$ for $30 \mathrm{~min}$ followed by inactivation at $95^{\circ} \mathrm{C}$ for $2 \mathrm{~min}$.

\section{Analysis of expression of genes associated with flavonoid biosynthesis}

The expression of key genes associated with flavonoid biosynthesis pathway was determined via quantitative real-time PCR (qRT- PCR (qTOWER 2.2, Analytic Jena, Germany) and data analysis has performed by aj, qPCRsoft 3.0. The gene expression analysis of selected genes (CHS, CHI, F3H, and FLS) in different culture systems were analyzed by using, the gene specific primers which were designed on the basis of sequence data procured from D. caryophyllus GenBank (National Center for Biotechnology Information; NCBI). The RT specific primers were designed using PrimerQuest tool (Integrated DNA Technologies, Inc., lowa 52241, USA) under default parameters. The designed primer sequences were 
again sorted by checking the specification of PCR primer status in Sequence Manipulation Suite; Version 2 software (Stothard 2000), and purchased (Geno Biosciences Pvt. Ltd, Noida, India). The designed primer sequences were duly tabulated to relative expression study (Table 1). The specificity of RT specific primers was found by melting curve analysis and single band product visualization by agarose gel electrophoresis. The expression of gene of interest was confirmed by using actin (ACT) as the internal control. qRT-PCR analysis was performed with 2X Real-Time PCR Master Mix with SYBERGreen (Origin Diagnostics and Research, Karunagapally, Kerala, India) by the intercalation of a fluorescent dye (SYBER ${ }^{R}$ Green) all in the volume of $20 \mu \mathrm{l}$. The thermal profile of the $\mathrm{CHS}, \mathrm{CHI}, \mathrm{F} 3 \mathrm{H}$, and FLS polymerase reaction was $95^{\circ} \mathrm{C}$ for $7 \mathrm{~min}$, followed by 40 cycles of $95^{\circ} \mathrm{C}$ denaturation for $20 \mathrm{~s}, 48.2^{\circ} \mathrm{C},(\mathrm{CHS}), 48.9^{\circ} \mathrm{C}(\mathrm{CHI})$, $48.0^{\circ} \mathrm{C}(\mathrm{F} 3 \mathrm{H})$, or $48.9^{\circ} \mathrm{C}(\mathrm{FLS})$ annealing for $15 \mathrm{~s}$ and $72^{\circ} \mathrm{C}$ extension for $15 \mathrm{~s}$. At the end of the program, the melting curve was activated by increasing the temperature from $60^{\circ} \mathrm{C}$ to $95^{\circ} \mathrm{C}$. Each copy number of all the genes was normalized against that of ACT and the relative expression was calculated by the 2 $\Delta \Delta \mathrm{CT}$ method (Livak and Schmittgen 2001).

\section{Statistical analysis}

All the experiments on callus cultures were conducted using a randomized complete block design (RCBD) method. Every experiment consists of four replication blocks of 10 culture tubes or 6 culture flasks for each treatment. To record callus induction as well as flavonoid production, parameters viz., percentage of response, fresh weight (g), dry weight (g), and total flavonoid (44 mg QE g-1 DW) were recorded every 20 days of culture. The data subjected to analysis of variance (ANOVA) and the differences among the mean values were compared with Duncan's Multiple Range Test (DMRT; $\mathrm{p}<0.05)$ using IBM SPSS Statistics V22.0 and all results were expressed as mean \pm SD. The RNA isolation was conducted with pooled replications, and data represented the mean relative expression of three repeats with standard error bars.

\section{Results And Discussion}

\section{In vitro callus induction}

Callus induction from intermodal or leaf segments cultivated on different auxin supplemented media showed distinct growth characters (Table 1). When explants were cultured on full strength MS medium containing 2.5 or $5 \mu \mathrm{M}$ 2, 4-D or picloram, induction of friable callus (100\%) was noticed (Fig. 1a and b), while the explants cultured on the media containing NAA, IAA, or IBA produced roots with low callus proliferation (Fig. 1c-e). In contrast to picloram 2,4- D facilitated higher callus biomass accumulation both in internode ( $2.13 \mathrm{~g} /$ culture) and leaf explants ( $0.78 \mathrm{~g} /$ culture). The response of $5 \mu \mathrm{M} 2,4$ - D also showed distinct callus morphology after 40 days cultures (Fig. 1f). The internodal segment showed superior response with creamy friable callus, while leaf explant showed inferior callogenic response and the developed callus was white, nodular type (Fig. $1 \mathrm{~g}$ and $\mathrm{h}$ ). Friable greenish-yellow callus was induced $(100 \%)$ after 1 week from the cut ends of the internode cultured on MS medium containing 2, 4- D (2.5 $\mu \mathrm{M})$ (Fig. 1i), and highly proliferative creamy callus formation occurred after one month of incubation. In contrast, the auxin-free cultures failed to produce callus irrespective of explants used. The loosely 
aggregated, friable callus mass induced by the intervention of 2,4- $\mathrm{D}$ is capable to grow rapidly with high cell proliferation (Souza et al. 2011). Due to superior response and high fresh weight, the internode derived calli were selected for further flavonoid production experiments. Similar callus proliferation response was reported in D. chinensis (Nontaswatsri et al. 2008) and D. caryophyllus (Maurya et al. 2019), where favourable effect of 2,4- D on callus formation from nodal explant compared to leaf segments. However, Teixeira da Silva (2014) reported the internodal explants of $D$. caryophyllus are suitable to produce callus using a combination of BA and 2, 4- D. Similar callus proliferation was reported in Sophora flavescens and suggest that addition of 2, 4- D or picloram in the callogenesis medium are more responsive than NAA (Park et al. 2020).

\section{Callus culture and flavonoid production}

The internode derived friable calli on different concentrations of 2,4- D at dark or light condition showed increase in size accompanied by efficient cell proliferation at every 20 days of culture. The auxin treatments revealed that type and concentration of $2,4-D$ have significant effect on $(p<0.05)$ fresh weight or dry weight accumulation in callus cultures (Table 2 and 3 ). Among the different incubation conditions, 2, 4- $\mathrm{D}$ at light condition was found to be the most effective for callus induction, producing rapidly growing friable calli (Fig. 2a). The friable greenish callus was formed from all the treatments within 1 week of culture. After 30 days, the callus tissues turned creamy to yellow colored, and later ( $80 \mathrm{~d})$, which appeared yellowish-brown. The nature of callus and production of bioactive compounds in medicinal herbs depends on various factors such as incubation conditions, type, and concentration of growth regulators used (Palacio et al. 2012; Castro et al. 2016; Park et al. 2020). The efficient callus induction in auxin treated medium is due to initiation of cell division, growth, and elongation; especially promoting microRNA transcription specific to growth related protein synthesis (George et al. 2008). Moreover, it is often cited that 2,4-D is a foremost suitable auxin specific to callus induction (Anjusha and Gangaprasad 2017; Farhadi et al. 2017; Farvardin et al. 2017).

The higher FW (11.0 g/ culture; Fig. 2b) was achieved on $10 \mu \mathrm{M}$ followed by $15 \mu \mathrm{M} 2$, 4- D (9.0 g/ culture) containing medium at $16 \mathrm{~h}$ light/ $8 \mathrm{~h}$ dark condition (Fig. 2c) and least $\left(3.2 \mathrm{mg} \mathrm{g}^{-1}\right)$ fresh biomass of callus formed at $1 \mu \mathrm{M}$ 2,4- D during 80 days incubation under complete dark condition (Fig. 2d). As the duration of incubation increased, the biomass accumulation also increased with respect to auxin concentration in light or dark condition. At dark condition, friable white callus (Fig. 2d) was proliferated on $10 \mu \mathrm{M}$ 2,4- $\mathrm{D}$ and upon extending the days of incubation to 80 days, colour of callus turned to yellowish brown (Fig. 2e and f). A gradual increase of dry weight was observed with increasing concentration of 2,4-D, regardless of incubation condition, whether it is light or dark, whereas the maximum dry weight of callus ( $0.38 \mathrm{~g} /$ culture) was recorded in $10 \mu \mathrm{M} 2,4-\mathrm{D}$ at light condition. These results are in agreement with that of Saensouk et al. (2007), who reported maximum callus in 2,4- D supplemented medium, incubated at light condition. Moreover, Sakpere et al. (2014) stated that 2,4- D is the better growth regulator for callus development and biomass production in Telfaria species as compared with other auxins. Dry weight accumulation of callus was found to be maximum at $60^{\text {th }}$ day of incubation in all the auxin concentrations. Thereafter, it declined possibly due to unavailability of 
nutrients or deterioration of callus due to accumulation of auto-toxic metabolic products. Alwash et al. (2018) reported the quick callogenic response characterized by the formation of friable, granular, or greenish yellow to creamy callus in $D$. caryophyllus using 2,4-D $\left(1 \mathrm{mg} \mathrm{L}^{-1}\right)$ and BA $\left(0.5 \mathrm{mg} \mathrm{L}^{-1}\right)$ added medium.

\subsubsection{Callus growth index and moisture content}

Growth index $(\mathrm{GI})$ of callus raised in $10 \mu \mathrm{M} 2$, 4- D were analyzed from $10^{\text {th }}$ day to $80^{\text {th }}$ day of culture at 10 days intervals. The growth curve of callus biomass showed sigmoid pattern at $10 \mu \mathrm{M} 2,4$ - D. Time course monitoring of callus growth suggests that an initial slow growth (lag phase) for first 30 days and there after sudden increase in $\mathrm{Gl}$ (log phase) ending at day 60 (Fig. 3a). Subsequently the linear phase was shifted to stationary phase after $60^{\text {th }}$ day of incubation. Callus maintained in medium containing 2 , 4- $\mathrm{D}(10 \mu \mathrm{M})$ for 80 days recorded $11 \mathrm{~g} \mathrm{FW/} \mathrm{culture} \mathrm{and} \mathrm{indicated} 55$-fold increase over the initial callus mass. Similarly, the callus moisture content increased significantly $(p<0.05)$ and proportionally to the fresh weight accumulation in 10 $\mu \mathrm{M}$ 2,4- D medium (Fig. 3b). Moderate level of moisture was accumulated up to $50^{\text {th }}$ day of incubation, there after upraised exponentially with increasing the period of incubation.

\subsubsection{Total flavonoid production}

Flavonoid production through callus culture on 2, 4- D added MS medium showed significant result both in light and dark condition (Table 5). Among different concentrations of 2, 4- D, $10 \mu \mathrm{M}$ found to be the most effective to produce callus as well as flavonoid. The highest flavonoid accumulation in 2,4- D fortified medium were noticed in $10 \mu \mathrm{M}$ concentration at dark condition (4.44 $\mathrm{mg} \mathrm{QE} \mathrm{g}^{-1} \mathrm{DW}$ ) on $60^{\text {th }}$ day of incubation. Flavonoid content of callus sampled showed steady increase up to $60^{\text {th }}$ day of sampling, thereafter production slightly declined. In comparison to the initial flavonoid content $\left(0.40 \mathrm{mg} \mathrm{QE} \mathrm{g}^{-1} \mathrm{DW}\right)$, cultures raised in 2, 4- D $(10 \mu \mathrm{M})$ containing medium after 60 days incubation in dark, 11.1-fold increase achieved. $10 \mu \mathrm{M}$ 2,4- D at $16 \mathrm{~h}$ light/ $8 \mathrm{~h}$ dark incubation resulted $3.85 \mathrm{mg} \mathrm{QE} \mathrm{g}^{-1} \mathrm{DW}$ leading 11.3-fold flavonoid production compared to initial 10 days culture and 19.25 -fold to control set. The incubation condition did show any significant role on flavonoid production and callus maintained in light condition produced slightly decreased concentration of flavonoid (Table 5) However, cultures raised in $10 \mu \mathrm{M}$ 2, 4-D and incubated in light condition ( $16 \mathrm{~h} \mathrm{light/} 8 \mathrm{~h}$ dark) has promoted enhanced biomass accumulation, thus contributed significantly to highest flavonoid yield.

The stability assay of flavonoid production on $10 \mu \mathrm{M} 2,4$ - D added medium at light condition revealed the stable metabolite production during four consecutive subcultures (Fig. 4). By considering the stability and flavonoid yield, $10 \mu \mathrm{M} 2$, 4- D under $16 \mathrm{~h}$ light condition was selected as the best hormone treatment for callus culture in $D$. chinensis. Our study indicated that calli at 60 days of incubation had high accumulation of total flavonoids. It is noticed that callus adapted to grow well in light condition, consequently obtain higher biomass, and seems to conducive flavonoid production and is in accordance 
to callus cultures of Sophora flavescens (Park et al. 2020), while Loredo-Carrillo et al. (2013) has reported the callus derived secondary metabolites were produced only in the presence of light.

In the present study, 2, 4- D stimulated the quiescent cell to multiply and the lack of exogenous supply of auxin in the medium (control) caused non-proliferation of callus tissue. Fresh weight and DW records of cultures raised in 2, 4- D added medium were upraised with increasing concentration as reported previously in different cultivars of $D$. caryophyllus (Singh et al. 2000; Jorapur et al. 2018). In a previous report, a crown gall transformed line of $D$. caryophyllus was used to produce type 1 ribosome- inactivating protein, dianthin (Messeguer et al. 1999). Alwash et al. (2018) reported the enhanced production of dianthalexin (phytoalexin) in callus cultures of $D$. chinensis raised in MS medium containing 2,4- D (1 mg $\mathrm{L}^{-1}$ ) and BA (0.5mg L $\left.\mathrm{m}^{-1}\right)$. Luczkiewicz and DanielGtód (2003) reported that 2, 4- D is the best hormone for flavonoid production in Genista sp., where an optimized incubation condition for callus growth was used. Combined effect of 2, 4- D and BA on the production callus derived flavonoid was reported in Artocarpus lakoocha (Maneechai et al. 2012). In a traditional Chinese medicinal herb, Dysosma pleiantha callus cultures took 10 weeks for its maximum growth to induce kaempferol or quercetin production (Karuppaiya and Tsay, 2019). The callus cultures of Ligaria cuneifolia were used to produce polyphenolic compounds viz., flavanols, hydroxyl cinnamic acid, proanthocyanidin and catechin (Ricco et al. 2019). There were many reports on production of anthocyanins from callus of different plant species such as Vaccinium myrphillus (Madhavi et al. 1998), Crataegus sinaica (Maharik et al. 2009). Previous works also supported the production of flavonoid derivatives like, luteolin from callus cultures of Hypericum perforatum (Dias et al. 1998) and isoflavonioids form Maackia amuresis (Fedoreyev et al. 2000) and Genista sp. (Luczkiewicz and Daniel Głód 2003). In recent times, the increment of flavonoid production in various in vitro culture systems were reported by way of over expression of flavonoid related genes in diverse plant groups (Li et al. 2006; Zhang et al. 2009; Park et al. 2011; Haida et al. 2019; Popova et al. 2020).

\section{qRT-PCR analysis on flavonoid related genes expression in callus culture}

The qRT-PCR amplification curve of CHS, $\mathrm{CHI}, \mathrm{F} 3 \mathrm{H}$ or FLS genes were generated using callus sampled in different time intervals and cycle threshold (CT) was determined at specific threshold fluorescent values. The specificity of 40 cycle amplification for each primer set along with ACTIN primers in callus sample was confirmed by the single peak melting curve of qRT-PCR products (Fig. 6). The presence of single bands with expected size in agarose (1.6\%; SRL, Mumbai, India) gel electrophoresis also showed the quality and specificity of PCR products.

The high concentration of flavonoid accumulated as well as proliferated callus tissues raised in MS medium containing $10 \mu \mathrm{M} 2,4-\mathrm{D}$, and incubated at normal photoperiod (16h light/8 h dark) was harvested at different time intervals $(1,20,40,60$, or 80 days) to isolate total RNA. The gene expression pattern during callus proliferation from initial stage of callus culture and the expression levels of genes involved in flavonoid biosynthetic pathway were determined by qRT-PCR analysis. The four candidate genes (CHS, $\mathrm{CHI}, \mathrm{F} 3 \mathrm{H}$, and FLS) studied, showed an up-regulation in transcript level from the callus inoculation day 
(Day 1; control; Fig. 7a-d). The results are in agreement to the tabulated total flavonoid accumulation in callus cultures at 20 days interval. Among the four genes analyzed, $\mathrm{CHS}, \mathrm{F} 3 \mathrm{H}$, and FLS displayed a significant increment of transcript abundance at $60^{\text {th }}$ day of sampled callus. However, at $80^{\text {th }}$ day, the expression reduced compared to callus sampled on $60^{\text {th }}$ day of culture. The relative expression of $\mathrm{CHS}$, $\mathrm{F} 3 \mathrm{H}$, and FLS gene was $11.59,48.31$, and 114.63 -fold higher at $60^{\text {th }}$ day respectively than the $1^{\text {st }}$ day of inoculation, whereas $\mathrm{CHI}$ transcript showed 26.35 -fold increment at $40^{\text {th }}$ day of inoculation. Through the present study it is reasonable to deduce that flavonoid biosynthesis potential of 60 days old callus is maximal.

The expression levels of flavonoid biosynthesis were explained by using these key genes in various culture systems (Rizzini et al. 2011; Huang et al. 2016). In the present study, the expression patterns of callus cultures in $D$. chinensis correspond with the total flavonoid accumulation in cultures incubated for 20 days at normal photoperiod. Flavonoid related gene ( $\mathrm{F} 3 \mathrm{H}$ and $\mathrm{CHS}$ ) expression in callus culture of Malus sieversii has enhanced under light condition than dark (Wang et al. 2016). The differential expression of flavonoid pigment anthocyanin biosynthesis genes (viz., PAL, CHS, CHI, DFR, and F3H) was reported in callus cultures of Daucus carota under varying concentrations of MS media constituents (Saad et al. 2018). It was reported PAL, CHS, and CHI transcript level increased at optimal concentration of $\mathrm{NH}_{4} \mathrm{NO}_{3}(40 \mathrm{mM})$ and $\mathrm{KNO}_{3}(18.8 \mathrm{mM})$ in the MS medium. An up-regulation of CHS2 and $\mathrm{CH} 1$ gene was reported during the enhanced production of flavonoids in hairy root cultures of Physalis angulata (Zhan et al. 2020). The flavonoid pathway related gene expression was conducted in callus cultures of Dimocarpus longan at different blue light conditions, where the genes $\mathrm{CHI}, \mathrm{CHS}, \mathrm{F} 3 \mathrm{H}, \mathrm{DFR}$ (dihydroxy flavonol reductase), and LAR (leucoanthocyanidin reductase) transcript level showed increasing upregulated trends under blue light upto $24 \mathrm{~h} /$ day except FLS gene (Li et al. 2018). However, the UV exposure treatment on hairy root cultures of Fagopyrum tataricum compared to untreated control, 30-40 fold FLS transcript abundance in flavonoid pathway was reported (Huang et al. 2016). In the present study, final gene expression of FLS under 2,4- D treatment showed the highest transcript abundance at $60^{\text {th }}$ day of growth phase, which was 114.63-fold higher than control. These much fold change of flavonoid gene (FLS) due to the gene flux, which targeted towards many pathways and might be significantly contributed net result of enhanced production of flavonoids. As such, based on expression profile it is entailed that 2,4- D steered callus growth, couple flavonoid accumulation by up-regulating a series of flavonoid biosynthesis-related genes. The work forwards, an excellent idea on over production of diverse flavonoid compound through the highly proliferated callus lines of $D$. chinensis.

\section{Conclusion}

In this study, we have developed an efficient callus culture system for in vitro study on flavonoid biosynthesis and found that 2,4- D had a significant effect on CHS, CHI, F3H, and FLS transcript level on specific time intervals. MS medium containing 10 $\mathrm{M}$ 2,4-D enhanced 11.59, 48.31, and 114.63 folds $\mathrm{CHS}, \mathrm{F} 3 \mathrm{H}$, and FLS transcript abundance respectively at 60th days of culturing. The study forwards an idea that serves to enhance the flavonoid production by focusing on transcript abundance in different 
callus phases. The developed culture system should provide a future research to apply new bio-technique tools on constructing novel flavonoid regulating sequence of the efficient, proliferated cell lines of $D$. chinensis

\section{Declarations}

\section{Acknowledgments}

The authors are grateful to Dr. TS Swapna, Professor and Head, Department of Botany, University of Kerala, Kariavattom, Thiruvananthapuram, for providing the facilities. The author also thank University of Kerala for financial support in the form of Junior Research Fellowship (No.AcVI(1)/715/BOT/13289/2015). Authors thank Director, Central Laboratory for Instrumentation and Facilitation (CLIF), University of Kerala for extending qRT-PCR facilities procured through DST-PURSE project, Govt. of India.

\section{Conflict of interest}

The authors declare no conflict of interest

\section{References}

1. Alwash B, Shlahi S, Hamad SF (2018) Impact of different ploidy levels change on dianthalexin content in Dianthus caryophyllus L. Asian J Microbiol Biotechnol Environ Sci 20:501-505

2. Anjusha S, Gangaprasad A (2017) Callus culture and in vitro production of anthraquinone in Gynochthodes umbellata (L.) Razafim. \& B. Bremer (Rubiaceae). Ind Crop Prod 95: 608-614. https://doi.org/10.1016/j.indcrop.2016.11.021

3. Azuma A, Yakushiji H, Koshita Y, Kobayashi S (2012) Flavonoid biosynthesis- related genes in grape skin are differentially regulated by temperature and light conditions. Planta 236:1067-1080. https://doi.org/10.1007/s00425-012-1650-x

4. Biswasa T, Mathura A, Guptaa V, Luqmanb S, Mathura AK (2020) Elicitation and phenylalanine precursor feeding based modulation of in vitro anthocyanin production, enzyme activity and gene expression in an Indian ginseng congener- Panax sikkimensis Ban. Ind Crops Prod 145:111986. https://doi.org/10.1016/j.indcrop.2019.111986

5. Castro AHF, Braga KQ, Sousa FM, Coimbra MC, Chagas RCR (2016) Callus induction and bioactive phenolic compounds production from Byrsonima verbascifolia (L.) Dc. (Malpighiaceae). Rev Cienc Agron 47:143-151. https://doi.org/10.5935/1806-6690.20160017

6. Chang C, Yang M, Wen H, Chern J (2002) Estimation of total flavonoid content in Propolis by two complementary colorimetric methods. J Food Drug Anal 10:178-182. https://doi.org/10.38212/2224-6614.2748 
7. Curir P, Dolci M, Dolci P, Lanzotti V, De Cooman L (2003) Fungitoxic phenols from carnation (Dianthus caryophyllus) effective against Fusarium oxysporum f. sp. dianthi. Phytochem Anal 14:8-12. https://doi.org/10.1002/pca.672

8. Dias MI, Sousa MJ, Alves RC, Ferreira IC (2016) Exploring plant tissue culture to improve the production of phenolic compounds: A review. Ind Crops Prod 82:9-22

9. Duan $Y$, Zhang H, Meng X et al (2019) Accumulation of salicylic acid-elicited alkaloid compounds in in vitro cultured Pinellia ternata microtubers and expression profiling of genes associated with benzoic acid-derived alkaloid biosynthesis. Plant Cell Tiss Org Cult 139:317-325. https://doi.org/10.1007/s11240-019-01685-5

10. Farhadi N, Panahandeh J, Azar AM, Salte SA (2017) Effects of explant type, growth regulators and light intensity on callus induction and plant regeneration in four ecotypes of Persian shallot (Allium hirtifolium). Sci Hortic 218:80-86. https://doi.org/10.1016/j.scienta.2016.11.056

11. Farvardin A, Ebrahimi A, Hosseinpour B, Khosrowshahli M (2017) Effects of growth regulators on callus induction and secondary metabolite production in Cuminum cyminum. Nat Prod Res 31:1963-1970. https://doi.org/10.1080/14786419.2016.1272105

12. Fedoreyev SA, Pokushalova TV, Veselova MV, Glebko LI, Kulesh NI, Muzarok TI, Seletskaya LD, Bulgakov VP, Zhuravlev YN (2000) Isoflavonoid production by callus cultures of Maackia amurensis. Fitoterapia 71:365-372. https://doi.org/10.1016/S0367-326X(00)00129-5

13. Fu X, Yang S, Bao M (2008) Factors affecting somatic embryogenesis in anther cultures of Chinese pink (Dianthus chinensis L.). In Vitro Cell Dev Biol Plant 44:194-202. https://doi.org/10.1007/s11627-008-9107-4

14. Galeotti F, Barile E, Curir P, Dolci M, Lanzotti V (2008a) Flavonoids from carnation (Dianthus caryophyllus) and their antifungal activity. Phytochem Lett 1:44-48. https://doi.org/10.1016/j.phytol.2007.10.001

15. Galeotti F, Barile E, Lanzotti V, Dolci M, Curir P (2008b) Quantification of major flavonoids in carnation tissues (Dianthus caryophyllus) as a tool for cultivar discrimination. J Biosci 63:161-168. https://doi.org/10.1515/znc-2008-3-401

16. George EF, Hall MA, De Klerk GJ (2008) Plant Propagation by Tissue Culture, vol 1, 3rd edn. Springer, Berlin, pp 175-226

17. Godoy-Hernandez G, Vazquez-flota FA (2006) Estimation of cell division and cell expansion. In: Loyola-Vargas, Vazquez-flota (eds) Methods in Molecular Biology, Plant Cell Culture Protocols. Humana Press, New York Inc, pp 51-58

18. Haida Z, Syahida A, Ariff SM et al (2019) Factors affecting cell biomass and flavonoid production of Ficus deltoidea var. kunstleri in cell Suspension culture system. Sci Rep 9:9533. https://doi.org/10.1038/s41598-019-46042-w

19. Jiangsu New Medical College (1977) The Dictionary of Chinese Crude Drugs. In: Zhong Yao Da Ci Dian (ed) Shanghai Science and Technology Press, Shanghai 
20. Hichri I, Barrieu F, Bogs J, Kappel C, Delrot S, Lauvergeat V (2011) Recent advances in the transcriptional regulation of the flavonoid biosynthetic pathway. J Exp Bot 62:2465-2483. https://doi.org/10.1093/jxb/erq442

21. Huang X, Yao J, Zhao Y, Xie D, Jiang X, Xu Z (2016) Efficient rutin and quercetin biosynthesis through flavonoids- related gene expression in Fagopyrum tataricum Gaertn. hairy root cultures with UV-B irradiation. Front Plant Sci 7:63. https://doi.org/10.3389/fpls.2016.00063

22. Jaakola L, Määttä-Riihinen K, Kärenlampi S, Hohtola A (2004) Activation of flavonoid biosynthesis by solar radiation in bilberry (Vaccinium myrtillus L.) leaves. Planta 218:721-728. https://doi.org/10.1007/s00425-003-1161-x

23. Jethwani V, Kothari SL (1996) Phenylacetic acid induced organogenesis in cultured leaf segments of Dianthus chinensis. Plant Cell Rep 15:869-872. https://doi.org/10.1007/BF00233159

24. Jiang F, Wang JY, Jia HF, Jia WS, Wang H, Xiao M (2013) RNAi mediated silencing of the flavanone 3-hydroxylase gene and its effect on flavonoid biosynthesis in strawberry fruit. J Plant Growth Regul 32:182-190. https://doi.org/10.1007/s00344-012-9289-1

25. Jorapur S, Jogdande N, Dhumale D (2018) Petal callus mediated de novo regeneration of shoots in carnation (Dianthus caryophyllus L.). The Pharma Innov J 7:218-222

26. Kabita KC, Sharma SK, Sanatombi K (2019) Analysis of capsaicinoid biosynthesis pathway genes expression in callus cultures of Capsicum chinense Jacq. cv. 'Umorok' Plant Cell Tiss Organ Cult 137:565-573. https://doi.org/10.1007/s11240-019-01591-w

27. Kantia A, SL Kothari (2002) High efficiency adventitious shoot bud formation and plant regeneration from leaf explants of Dianthus chinensis L. Sci Hort 96:205-212. https://doi.org/10.1016/S03044238(02)00081-X

28. Karuppaiya P, Tsay HS (2019) Enhanced production of podophyllotoxin, kaempferol, and quercetin from callus culture of Dysosma pleiantha (Hance) Woodson: An endangered medicinal plant. Biotechnol Appl Biochem 67:95-104. https://doi.org/10.1002/bab.1810

29. Koes R, Verweij W, Quattrocchio F (2005) Flavonoids: a colorful model for the regulation and evolution of biochemical pathways. Trends Plant Sci 10:236-242.

https://doi.org/10.1016/j.tplants.2005.03.002

30. Kumar MS, Chaudhury S, Balachandran S (2014) In vitro callus culture of Heliotropium indicum Linn. for assessment of total phenolic and flavonoid content and antioxidant activity. Appl Biochem Biotechnol 174:2897-2909. https://doi.org/10.1007/s12010-014-1235-1

31. Kumar P, Partap M, Ashrita, Rana D, Kumar P, Ashish RW (2020) Metabolite and expression profiling of steroidal alkaloids in wild tissues compared to bulb derived in vitro cultures of Fritillaria roylei high value critically endangered Himalayan medicinal herb. Ind Crop Prod 145:111945. https://doi.org/10.1016/j.indcrop.2019.111945

32. Kumar S, Chashoo G, Saxena AK, Pandey AK (2013) Parthenium hysterophorus: a probable source of anticancer, antioxidant and anti-HIV agents. Biome Res Int 3:810734. https://doi.org/10.1155/2013/810734 
33. Lepiniec L, Debeaujon I, Routaboul JM, Baudry A, Pourcel L, Nesi N, Caboche M (2006) Genetics and biochemistry of seed flavonoids. Annu Rev Plant Biol 57:405-430.

https://doi.org/10.1146/annurev.arplant.57.032905.105252

34. Li F, Jin Z, Qu W, Zhao D, Ma F (2006) Cloning of cDNA encoding the Saussurea medusa chalcone isomerase and its expression in transgenic tobacco. Plant Physiol Biochem 44:455-461. https://doi.org/10.1016/j.plaphy.2006.08.006

35. Li H, Lin Y, i Chen X, Bai Y, Wang C, Xu X, Wang Y, Lai Z (2018) Effects of blue light on flavonoid accumulation linked to the expression of miR393, miR394 and miR395 in longan embryogenic calli. PLoS ONE 13:e0191444. https://doi.org/10.1371/journal.pone.0191444

36. Livak KJ, Schmittgen TD (2001) Analysis of relative gene expression data using real-time quantitative PCR and the $2^{-\Delta \Delta C T}$ method. Methods 25:402-408.

https://doi.org/10.1006/meth.2001.1262

37. López-Expósito I, Castillo A, Yang N, Liang B, Li X-M (2011) Chinese herbal extracts Rubia cordifolia and Dianthus superbus suppress lgE production and prevent peanut-induced anaphylaxis. Chinese medicine 6:35. https://doi.org/10.1186/1749-8546-6-35

38. Loredo-Carrillo SE, de Lourdes S-DM, Leyva E, del Socorro S-DM (2013) Establishment of callus from Pyrostegia venusta (Ker Gawl.) Miers and effect of abiotic stress on flavonoids and sterols accumulation. J Plant Biochem Biotechnol 22:312-318. https://doi.org/10.1007/s13562-012-0161-y

39. Lucho SR, do Amaral MN, Milech C et al (2018) Elicitor-induced transcriptional changes of genes of the steviol glycoside biosynthesis pathway in Stevia rebaudiana Bertoni. J Plant Growth Regul 37:971-985. https://doi.org/10.1007/s00344-018-9795-x

40. Luczkiewicz M, DanielGłód (2003) Callus cultures of Genista plants-in vitro material producing high amounts of isoflavones of phytoestrogenic activity. Plant Sci 165:1101-1108. https://doi.org/10.1016/S0168-9452(03)00305-4

41. Luo J, Chen X, Kong L (2011) Three new triterpenoid saponins from Dianthus superbus. Chem Pharm Bull 59:518-521. https://doi.org/10.1248/cpb.59.518

42. Ma L, Gu Y, Luo J, Wang J, Huang X, Kong L (2009) Triterpenoid saponins from Dianthus versicolor. J Nat Prod 72:640-644. https://doi.org/10.1021/np800589a

43. Madhavi DL, Bomser JA, Smith MA, Singletary KW (1998) Isolation of bioactive constituents from Vaccinium myrtillus (bilberry) fruits and cell cultures. Plant Sci 131:95-103. https://doi.org/10.1016/S0168-9452(97)00241-0

44. Maharik N, Elgengaihi S, Taha H (2009) Anthocyanin production in callus cultures of Crataegus sinaica Boiss. Inter J Acad Res 1:30-34

45. Maneechai S, De-Eknamku W, Umehara K, Noguchi H, Likhitwitayawuid K (2012) Flavonoid and stilbenoid production in callus cultures of Artocarpus lakoocha. Phytochem 81:42-49. https://doi.org/10.1016/j.phytochem.2012.05.031

46. Masoumian M, Ariff A, Ahmad S, Maziah M (2011) Effect of precursors on flavonoid production by Hydrocotyle bonariensis callus tissues. African J Biotechnol 10:6021-6029. 
https://doi.org/10.5897/AJB10.1480

47. Maurya RL, Sharma MK, Yadav MK, Kumar G, Kumar M (2019) In vitro high-frequency callus induction in carnation (Dianthus caryophyllus L.) cultivar "Irene". Plant Cell Biotechnol Mol Biol $20: 1363-1368$

48. Messeguer J, Marcozzi G, Spanò L (1999) In vitro production of dianthin from crown gall lines of carnation (Dianthus caryophyllus L.). Plant Cell Reps 18:451-455.

https://doi.org/10.1007/s002990050602

49. Nabavi SM, Samecb D, Tomczykc M, Milellad L et al (2020) Flavonoid biosynthetic pathways in plants: versatile targets for metabolic Engineering. Biotechnol Adv 38:107316. https://doi.org/10.1016/j.biotechadv.2018.11.005

50. Nakatsuka T, Saito M, Yamada E, Fujita K, Kakizaki Y, Nishihara M (2012) Isolation and characterization of GtMYBP3 and GtMYBP4, orthologues of R2R3-MYB transcription factors that regulate early flavonoid biosynthesis, in gentian flowers. J exp bot 63:6505-6517. https://doi.org/10.1093/jxb/ers306

51. Nho KJ, Chun JM, Kim HK (2012) Ethanol extract of Dianthus chinensis L. induces apoptosis in human hepatocellular carcinoma HepG2 cells in vitro. Evid Based Complement Alternat Med 573527. https://doi.org/10.1155/2012/573527

52. Nishiumi S, Miyamoto S, Kawabata K, Ohnishi K, Mukai R, Murakami A, Ashida H, Terao J (2011) Dietary flavonoids as cancer-preventive and therapeutic biofactors. Front Biosci 3.1332-1362. https://doi.org/10.2741/229

53. Nontaswatsri C, Fukai S, Ruamrungsri S (2008) Callus induction and plant regeneration of Dianthus chinensis L. and Dianthus barbatus L. via Anther culture. Acta Hort 788:109-114. https://doi.org/10.17660/ActaHortic.2008.788.12

54. Obmann A, Werner I, Presser A, ZehI M, Swoboda Z, Purevsuren S, Narantuya S, Kletter C, Glas S (2011) Flavonoid C- and O-glycosides from the Mongolian medicinal plant Dianthus versicolor Fisch. Carbohydrate Res 346:1868-1875. https://doi.org/10.1016/j.carres.2011.04.031

55. Oh Y, Jeong YH, Cho W, Hwang Y, Ma JY (2018) Inhibitory effects of Dianthi Herba ethanolic extract on inflammatory and nociceptive responses in murine macrophages and mouse models of abdominal writhing and ear edema. J Ethnopharmacol 211:375-383. https://doi.org/10.1016/j.jep.2017.09.010

56. Oshima Y, Ohsawa T, Hikino H (1984) Structures of Dianosides G, H and I, triterpenoid saponins of Dianthus superbus var. longicalycinus Herbs1. Planta Med 50:254-258. https://doi.org/10.1055/s2007-969692

57. Palacio L, Cantero JJ, Cusidó RM, Goleniowski ME (2012) Phenolic compound production in relation to differentiation in cell and tissue cultures of Larrea divaricata (cav.). Plant Sci 193:1-7. https://doi.org/10.1016/j.plantsci.2012.05.007

58. Pareek A, Kantia A, Kothari SL (2004) In vitro cloning of ornamental species of Dianthus. Indian J Biotechnol 3:263-266. http://hdl.handle.net/123456789/5853 
59. Park J-S, Seong Z-K, Kim M-S, Ha J-H, Moon K-B, Lee H-J, Lee H-K, Jeon J-H, Park SU, Kim H-S (2020) Production of flavonoids in callus cultures of Sophora flavescens Aiton Plants 9: 688; https://doi.org/10.3390/plants9060688

60. Park NI, Xu H, Li XH, Kim SJ, Park SU (2011) Enhancement of flavone levels through overexpression of chalcone isomerase in hairy root cultures of Scutellaria baicalensis. Funct Integr Genomics 11:3491-3496. https://doi.org/10.1007/s10142-011-0229-0

61. Popova P, Zarev Y, Shkondrov A, Krasteva I, Ionkova I (2020) Induction of flavonoid biosynthesis by in vitro cultivation of Astragalus glycyphyllos L. Pharmacia 67:95-99. https://doi.org/10.3897/pharmacia.67.e50390

62. Raman G, Park S (2015) Analysis of the complete chloroplast genome of a medicinal plant, Dianthus superbus var. longicalyncinus, from a comparative genomics perspective. PLoS One 10: e0141329. https://doi.org/10.1371/journal.pone.0141329

63. Ricco MV, Bari ML, Bagnato F, Cornacchioli, Laguia-Becher M, Spairani LU, Posadaz A, Dobrecky C, RiccoRA, Wagner ML, Álvarez MA (2019) Establishment of callus-cultures of the Argentinean mistletoe, Ligaria cuneifolia (R. et P.) Tiegh (Loranthaceae) and screening of their polyphenolic content. Plant Cell Tiss Org Cult 138:167-180. https://doi.org/10.1007/s11240-019-01615-5

64. Rizzini L, Favory JJ, Cloix C, Faggionato D, O'Hara A, Kaiserli E et al (2011) Perception of UV-B by the Arabidopsis UVR8 protein. Sci 332:103-106. https://doi.org/10.1126/science.1200660

65. Saad KR, Kumar G, Giridhar P, Shetty NP (2018) Differential expression of anthocyanin biosynthesis genes in Daucus carota callus culture in response to ammonium and potassium nitrate ratio in the culture medium. 3 Biotech 8:431. https://doi.org/10.1007/s13205-018-1447-0

66. Saensouk P, Theerakulpisut P, Kijwijan B, Bunnag S (2007) Effects of 2,4- D on callus induction from leaf explants of Cornukaempferia larsenii P. Gard Bull Singap 59:183-188

67. Sakpere AMA, Ajayi SA, Adelusi AA (2014) Effect of growth regulators and explant types on callus induction in Telfairia occidentalis Hook. Afric J Biotechnol 13:2015-2021. https://doi.org/10.5897/AJB2013.12919

68. Schijlen EG, Ric de Vos CH, van Tunen AJ, Bovy AG (2004) Modification of flavonoid biosynthesis in crop plants. Phytochem 65:2631-2648. https://doi.org/10.1016/j.phytochem.2004.07.028

69. Shin JA, Kim JJ, Choi ES, Shim JH, Ryu MH, Kwon KH, Park HM, Seo JY, Lee SY, Lim DW, Cho NP, Cho SD (2013) In vitro apoptotic effects of methanol extracts of Dianthus chinensis and Acalypha australis L. targeting specificity protein 1 in human oral cancer cells. Head Neck 35:992-998. https://doi.org/10.1002/hed.23072

70. Simms D, Cizdziel PE, Chomczynski P (1993) TRIZO ${ }^{\mathrm{TM}}$ : a new reagent for optimal single-step isolation of RNA. Focus 15:99-103

71. Singh KP, Suchitra, Gupta S (2000) Rapid organogenesis in carnation. J Orna Hort 3:120-121

72. Skrzypczak-Pietraszek E, Piska K, Pietraszek J (2018) Enhanced production of the pharmaceutically important polyphenolic compounds in Vitex agnus castus L. shoot cultures by precursor feeding strategy. Eng Life Sci 18:287-297. https://dx.doi.org/10.1002\%2Felsc.201800003 
73. Souza JMM, Tomaz ML, Arruda SCC, Demétrio CGB, Venables WN, Martinelli AP (2011) Callus sieving is effective in improving synchronization and frequency of somatic embryogenesis in Citrus sinensis. Biol Plantarum 55:703-307. https://doi.org/10.1007/s10535-011-0171-y

74. Sreelekshmi R, Siril EA (2020) Influence of polyamines on hyperhydricity reversion and its associated mechanism during micropropagation of China pink (Dianthus chinensis L.). Physiol Mol Biol Plants 26:2035-2045. https://doi.org/10.1007/s12298-020-00885-0

75. Sreelekshmi R, Siril EA (2021a) Investigation on in vitro bouquets and flower longevity of micropropagated Dianthus chinensis L. Sci Hortic 275:109708.

https://doi.org/10.1016/j.scienta.2020.109708

76. Sreelekshmi R, Siril EA (2021b) Effective reversal of hyperhydricity leading to efficient micropropagation of Dianthus chinensis L. 3 Biotech 11:95. https://doi.org/10.1007/s13205-02102645-7

77. Sreelekshmi R, Siril EA, Muthukrishnan S (2021) Role of biogenic silver nanoparticles on hyperhydricity reversion in Dianthus chinensis L. an in vitro model culture. J Plant Growth Regul. https://doi.org/10.1007/s00344-020-10276-0

78. Stothard $P$ (2000) The sequence manipulation suite: JavaScript programs for analyzing and formatting protein and DNA sequences. Biotechniques 28:1102-1104. https://doi.org/10.2144/00286ir01

79. Stracke R, Ishihara H, Sagasser M, Martens S, Weisshaar B (2009) Metabolomic and genetic analyses of flavonol synthesis in Arabidopsis thaliana support the in vivo involvement of leucoanthocyanidin dioxygenase. Planta 229:427-445. https://doi.org/10.1007/s00425-008-0841-y

80. Teixeira da Silva JA (2014) Callus Induction From 15 Carnation (Dianthus caryophyllus L.) Cultivars. J Plant Develop 21:15-21

81. Tohge T, de Souz LP, Fernie AR (2017) Current understanding of the pathways of flavonoid biosynthesis in model and crop plants. J Exp Bot 68:4013-4028. https://doi.org/10.1093/jxb/erx177

82. Tunen AJV, Koes RE, Spelt CE, Krol ARVD, Stuitje AR, Mol JN (1988) Cloning of the two chalcone flavanone isomerase genes from Petunia hybrida: coordinate, light-regulated and differential expression of flavonoid genes. EMBO J 7:1257-1263

83. Ververidis F, Trantas E, Douglas C, Vollmer G, Kretzschmar G, Panopoulos N (2007) Biotechnology of flavonoids and other phenylpropanoid-derived natural products. Part I. Chemical diversity, impacts on plant biology and human health. Biotechnol J 2:1214-1234.

https://doi.org/10.1002/biot.200700084

84. Wang J, Qian J, Yao L et al (2015) Enhanced production of flavonoids by methyl jasmonate elicitation in cell suspension culture of Hypericum perforatum. Bioresour Bioproc 2:5. https://doi.org/10.1186/s40643-014-0033-5

85. Wang N, Zhang Z, Jiang S, Xu H, Wang Y, Feng S, Chen X (2016) Synergistic effects of light and temperature on anthocyanin biosynthesis in callus cultures of red-fleshed apple (Malus sieversii $\mathrm{f}$. niedzwetzkyana). Plant Cell Tiss Org Cult 127:217-227. https://doi.org/10.1007/s11240-016-1044-z 
86. Wang YC, Tan NH, Zhou J, Wu HM (1998) Cyclopeptides from Dianthus superbus. Phytochem 49:1453-1456. https://doi.org/10.1016/S0031-9422(97)00857-1

87. Wang J, Xiao X, Wang Q et al (2013) Accumulation of flavonoids and antioxidant activity of Stellera chamaejasme by an efficient callus culture. Hortic Environ Biotechnol 54:441-449. https://doi.org/10.1007/s13580-013-0171-2

88. Wasson AP, Pellerone FI, Mathesius U (2006) Silencing the flavonoid pathway in Medicago truncatula inhibits root nodule formation and prevents auxin transport regulation by rhizobia. Plant Cell 18:1617-1629. https://doi.org/10.1105/tpc.105.038232

89. Zhan X, Luo X, He J, Zhang C, Liao X, Xu X et al (2020) Bioactive compounds induced in Physalis angulata L. by methyl-jasmonate: an investigation of compound accumulation patterns and biosynthesis-related candidate genes. Plant Mol Biol. https://doi.org/10.1007/s11103-020-00996-y

90. Zhang H, Liu J, Lu H, Gao S (2009) Enhanced flavonoid production in hairy root cultures of Glycyrrhiza uralensis Fisch by combining the over-expression of chalcone isomerase gene with the elicitation treatment. Plant Cell Rep 28:1205-1213. https://doi.org/10.1007/s00299-009-0721-3

91. Zheng J, An Y, Wang L (2018) 24-Epibrassinolide enhances 5-ALA-induced anthocyanin and flavonol accumulation in calli of 'Fuji' apple flesh. Plant Cell Tiss Organ Cult 134:319-330. https://doi.org/10.1007/s11240-018-1418-5

92. Zhou Y, Jiao Y, Sun Y, Gao S (2020) In vitro production and distribution of flavonoids in Glycyrrhiza uralensis Fisch. J Food Sci Technol 57:1553-1564. https://doi.org/10.1007/s13197-019-04191-w

\section{Tables}

Table 1. Nucleotide sequences of primers used for flavonoid related gene expression study

\begin{tabular}{|lll|}
\hline Gene ID & NCBI ID & Primer sequence $\left(\mathbf{5}^{\mathbf{} \rightarrow \mathbf{3}^{\mathbf{}} \mathbf{)}}\right.$ \\
\hline CHS & MK416198.1 & F: AAGGTCCTGCGACTATTT \\
\hline CHI & LC377269.1 & F: CCAGGAGACTCCATTCTATT \\
\hline F3H & LC377194.1 & F: CGTGACGTATTTCTCATACC \\
\hline FLS & KM203112.1 & F: CGTAAAGTTGAGGAGAATGG \\
\hline & & R: TGAACCCGTCATCAGTAG \\
\hline ACTIN & AY007315 & F: TTTGGACTCTGGTGATGGTG \\
\hline & & R: CAGCCAAATCAAGACGCAAG \\
\hline
\end{tabular}


Table 2. Effect of different auxins on callus development from internode and leaf explants of $D$. chinensis

\begin{tabular}{|c|c|c|c|c|c|}
\hline \multirow{2}{*}{$\begin{array}{l}\text { Auxin } \\
\text { type }\end{array}$} & \multirow{2}{*}{$\begin{array}{l}\text { Concentration } \\
(\mu \mathrm{M})\end{array}$} & \multicolumn{2}{|c|}{ Internode explants } & \multicolumn{2}{|l|}{ Leaf explants } \\
\hline & & $\begin{array}{l}\text { Callus } \\
\text { induction (\%) }\end{array}$ & $\begin{array}{l}\text { Fresh weight (g/ } \\
\text { culture) }\end{array}$ & $\begin{array}{l}\text { Callus } \\
\text { induction (\%) }\end{array}$ & $\begin{array}{l}\text { Fresh weight (g/ } \\
\text { culture) }\end{array}$ \\
\hline Control & 0 & $0.00 \pm 0.00^{\mathrm{g}}$ & $0.00 \pm 0.00^{d}$ & $0.00 \pm 0.00^{e}$ & $0.00 \pm 0.00^{e}$ \\
\hline \multirow[t]{2}{*}{ NAA } & 2.5 & $6.67 \pm 3.33^{\mathrm{fg}}$ & $0.10 \pm 0.02^{d}$ & $3.33 \pm 3.33^{\mathrm{e}}$ & $0.04 \pm 0.02^{\mathrm{e}}$ \\
\hline & 5 & $13.3 \pm 6.66^{\text {ef }}$ & $0.11 \pm 0.03^{d}$ & $6.67 \pm 3.33^{e}$ & $0.05 \pm 0.03^{e}$ \\
\hline \multirow[t]{2}{*}{ IAA } & 2.5 & $23.33 \pm 3.33^{\mathrm{de}}$ & $0.11 \pm 0.04^{d}$ & $20.0 \pm 5.77^{d}$ & $0.05 \pm 0.03^{e}$ \\
\hline & 5 & $33.3 \pm 8.82^{\mathrm{cd}}$ & $0.17 \pm 0.03^{d}$ & $30.0 \pm 5.77^{c d}$ & $0.08 \pm 0.03^{e}$ \\
\hline \multirow[t]{2}{*}{ IBA } & 2.5 & $40.0 \pm 5.77^{b c}$ & $0.27 \pm 0.05^{d}$ & $33.3 \pm 3.33^{c}$ & $0.08 \pm 0.03^{e}$ \\
\hline & 5 & $50.0 \pm 5.77^{b}$ & $0.32 \pm 0.03^{d}$ & $46.67 \pm 6.66^{b}$ & $0.10 \pm 0.02^{\mathrm{e}}$ \\
\hline \multirow[t]{2}{*}{$2,4-D$} & 2.5 & $100.0 \pm 0.00^{\mathrm{a}}$ & $1.57 \pm 0.50^{b}$ & $100.0 \pm 0.00^{a}$ & $0.66 \pm 0.14^{b}$ \\
\hline & 5 & $100.0 \pm 0.00^{\mathrm{a}}$ & $2.13 \pm 0.32^{\mathrm{a}}$ & $100.0 \pm 0.00^{\mathrm{a}}$ & $0.78 \pm 0.05^{\mathrm{a}}$ \\
\hline \multirow[t]{2}{*}{ Picloram } & 2.5 & $96.7 .0 \pm 3.33^{a}$ & $1.10 \pm 0.10^{c}$ & $93.3 .0 \pm 3.33^{\mathrm{a}}$ & $0.35 \pm 0.06^{d}$ \\
\hline & 5 & $100.0 \pm 0.00^{\mathrm{a}}$ & $1.70 \pm 0.26^{b}$ & $96.7 \pm 3.33^{a}$ & $0.49 \pm 0.07^{c}$ \\
\hline \multicolumn{2}{|c|}{ Main effect Df $(n-1)=10$} & $95.93 * \star \star$ & $45.57 * \star \star$ & $113.28^{\star \star \star}$ & $75.35^{\star \star *}$ \\
\hline
\end{tabular}

$\star \star \star$ Significant at $p<0.001$ level, means within column followed by same letters are not significantly $(p<0.05)$ different as determined by Duncan's Multiple Range

Table 3. Fresh weight ( $\mathrm{g} /$ culture) biomass accumulation in internode derived callus cultures of $D$. chinensis 


\begin{tabular}{|c|c|c|c|c|c|c|}
\hline \multirow[t]{2}{*}{$\begin{array}{l}\text { Incubation } \\
\text { condition }\end{array}$} & \multirow[t]{2}{*}{$\begin{array}{l}\text { 2,4-D } \\
\text { Conc. }(\mu \mathrm{M})\end{array}$} & \multicolumn{5}{|c|}{$\begin{array}{l}\text { Fresh weight ( } \mathrm{g} / \text { culture) estimated during different incubation } \\
\text { periods (days) }\end{array}$} \\
\hline & & 10 & 20 & 40 & 60 & 80 \\
\hline & 2.5 & $0.22 \pm 0.01^{d}$ & $0.47 \pm 0.02^{\mathrm{cd}}$ & $1.3 \pm 0.18^{\mathrm{e}}$ & $2.7 \pm 0.15^{\mathrm{e}}$ & $4.5 \pm 036^{f}$ \\
\hline \multirow[t]{5}{*}{ Light } & 5.0 & $0.36 \pm 0.01^{c}$ & $0.62 \pm 0.03^{b}$ & $3.1 \pm 0.12^{c}$ & $5.5 \pm 0.17^{b c}$ & $8.0 \pm 0.14^{c}$ \\
\hline & 10 & $0.51 \pm 0.02^{\mathrm{a}}$ & $0.84 \pm 0.02^{\mathrm{a}}$ & $5.1 \pm 0.61^{\mathrm{a}}$ & $8.3 \pm 0.29^{a}$ & $11.0 \pm 0.14^{\mathrm{a}}$ \\
\hline & 15 & $0.42 \pm 0.02^{b}$ & $0.67 \pm 0.02^{\mathrm{b}}$ & $3.8 \pm 0.22^{b}$ & $5.9 \pm 0.07^{b}$ & $9.0 \pm 0.11^{\mathrm{b}}$ \\
\hline & Control (0) & $0.22 \pm 0.01^{d}$ & $0.23 \pm 0.01^{f}$ & $0.25 \pm 0.01^{f}$ & $0.25 \pm 0.02^{g}$ & $0.25 \pm 0.02^{h}$ \\
\hline & 2.5 & $0.22 \pm 0.01^{d}$ & $0.33 \pm 0.03^{\mathrm{e}}$ & $1.1 \pm 0.10^{e}$ & $2.0 \pm 0.26^{f}$ & $3.2 \pm 0.10^{\mathrm{g}}$ \\
\hline \multirow[t]{4}{*}{ Dark } & 5.0 & $0.25 \pm 0.02^{d}$ & $0.42 \pm 0.02^{d}$ & $1.9 \pm 0.15^{d}$ & $3.1 \pm 0.27 e$ & $6.3 \pm 0.22 \mathrm{e}$ \\
\hline & 10 & $0.44 \pm 0.02^{b}$ & $0.62 \pm 0.02^{b}$ & $3.2 \pm 0.36^{c}$ & $5.9 \pm 0.21 c^{d}$ & $7.3 \pm 0.29^{\text {de }}$ \\
\hline & 15 & $0.36 \pm 0.01^{c}$ & $0.54 \pm 0.03^{c}$ & $4.9 \pm 0.18^{c}$ & $6.3 \pm 0.16^{d}$ & $7.8 \pm 0.30^{d}$ \\
\hline & Control (0) & $0.22 \pm 0.01^{d}$ & $0.22 \pm 0.01^{f}$ & $0.23 \pm 0.01^{f}$ & $0.25 \pm 0.02^{\mathrm{g}}$ & $0.25 \pm 0.02^{h}$ \\
\hline \multicolumn{2}{|c|}{ Main effect Df $(n-1)=9$} & $48.81^{\star \star \star}$ & $64.26 * \star \star$ & $73.40 * \star \star$ & $143.21^{\star \star \star}$ & $224.36^{\star \star \star}$ \\
\hline \multicolumn{2}{|c|}{$\begin{array}{l}\text { Incubation condition(I) Df ( } \mathrm{n}- \\
1)=1\end{array}$} & $22.66^{\star \star \star}$ & $96.53^{\star \star \star}$ & 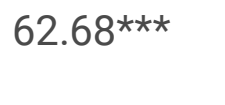 & 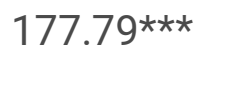 & 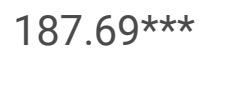 \\
\hline \multicolumn{2}{|c|}{ 2,4-D conc. (C) Df $(n-1)=4$} & $93.71 * \star \star$ & $149.49 * * \star$ & $177.05^{\star \star \star}$ & $343.28 * \star \star$ & $626.76^{\star \star \star}$ \\
\hline \multicolumn{2}{|c|}{$1 \times C D f(n-1)=9$} & $4.90 \star \star$ & $7.34 \star \star$ & $10.41 * \star \star$ & $24.67 * \star \star$ & $21.30 * \star \star$ \\
\hline
\end{tabular}

**Significant at $p<0.01$ level, $* * \star$ Significant at $p<0.001$ level, means within column followed by same letters are not significantly $(p<0.05)$ different as determined by Duncan's Multiple Range

Table 4. Fresh weight ( $\mathrm{g} /$ culture) biomass accumulation in internode derived callus cultures of $D$. chinensis 


\begin{tabular}{|c|c|c|c|c|c|c|}
\hline \multirow[t]{2}{*}{$\begin{array}{l}\text { Incubation } \\
\text { condition }\end{array}$} & \multirow[t]{2}{*}{$\begin{array}{l}2,4-\mathrm{D} \\
\text { Conc. } \\
(\mu \mathrm{M})\end{array}$} & \multicolumn{5}{|c|}{$\begin{array}{l}\text { Dry weight ( } \mathrm{g} / \text { culture) estimated during different incubation } \\
\text { periods (days) }\end{array}$} \\
\hline & & 10 & 20 & 40 & 60 & 80 \\
\hline & 2.5 & $0.01 \pm 0.00^{c}$ & $0.02 \pm 0.01^{c}$ & $0.07 \pm 0.01^{\mathrm{e}}$ & $0.16 \pm 0.02^{c}$ & $0.12 \pm 0.03^{c d}$ \\
\hline \multirow[t]{5}{*}{ Light } & 5.0 & $0.02 \pm 0.01^{b}$ & $0.02 \pm 0.00^{c}$ & $0.10 \pm 0.02^{\mathrm{cd}}$ & $0.25 \pm 0.04^{b c}$ & $0.16 \pm 0.02^{c}$ \\
\hline & 10 & $0.03 \pm 0.00^{\mathrm{a}}$ & $0.05 \pm 0.01^{\mathrm{a}}$ & $0.19 \pm 0.01^{\mathrm{a}}$ & $0.38 \pm 0.02^{\mathrm{a}}$ & $0.24 \pm 0.02^{\mathrm{a}}$ \\
\hline & 15 & $0.02 \pm 0.00^{b}$ & $0.03 \pm 0.00^{b}$ & $0.12 \pm 0.03^{c}$ & $0.26 \pm 0.04^{b}$ & $0.19 \pm 0.01^{b}$ \\
\hline & $\begin{array}{l}\text { Control } \\
\text { (0) }\end{array}$ & $0.01 \pm 0.00^{c}$ & $0.01 \pm 0.01^{d}$ & $0.02 \pm 0.01^{f}$ & $0.02 \pm 0.02^{d}$ & $0.02 \pm 0.03^{\mathrm{e}}$ \\
\hline & 2.5 & $0.01 \pm 0.00^{c}$ & $0.02 \pm 0.00^{c}$ & $0.09 \pm 0.01^{d}$ & $0.12 \pm 0.03^{d}$ & $0.09 \pm 0.00^{d}$ \\
\hline \multirow[t]{3}{*}{ Dark } & 5.0 & $0.01 \pm 0.00^{c}$ & $0.02 \pm 0.01^{c}$ & $0.12 \pm 0.02^{c}$ & $0.23 \pm 0.03^{b c}$ & $0.09 \pm 0.01^{d}$ \\
\hline & 10 & $0.02 \pm 0.00^{\mathrm{b}}$ & $0.03 \pm 0.00^{\mathrm{b}}$ & $0.19 \pm 0.04^{\mathrm{a}}$ & $0.33 \pm 0.04^{\mathrm{ab}}$ & $0.24 \pm 0.01^{\mathrm{a}}$ \\
\hline & 15 & $0.02 \pm 0.00^{b}$ & $0.03 \pm 0.02^{b}$ & $0.16 \pm 0.02^{b}$ & $0.31 \pm 0.02^{b}$ & $0.20 \pm 0.01^{b}$ \\
\hline Control & $\begin{array}{l}\text { Control } \\
\text { (0) }\end{array}$ & $0.01 \pm 0.00^{c}$ & $0.02 \pm 0.00^{c}$ & $0.02 \pm 0.01^{f}$ & $0.02 \pm 0.03^{d}$ & $0.02 \pm 0.00^{e}$ \\
\hline \multicolumn{2}{|c|}{ Main effect Df $(n-1)=9$} & $12.84^{\star \star \star}$ & $3.17 * \star$ & 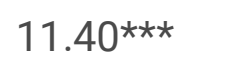 & $25.44^{\star \star \star}$ & $30.36 * \star \star$ \\
\hline \multicolumn{2}{|c|}{$\begin{array}{l}\text { Incubation condition (I) Df } \\
(n-1)=1\end{array}$} & $3.11^{*}$ & $4.44^{\star}$ & $3.27 *$ & 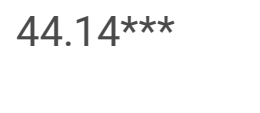 & $3.68^{*}$ \\
\hline \multicolumn{2}{|c|}{ 2,4-D conc. (C) Df $(n-1)=4$} & 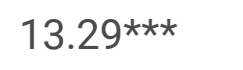 & $5.29 \star \star \star$ & 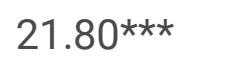 & $44.26 * \star \star$ & $59.05^{\star \star \star}$ \\
\hline \multicolumn{2}{|c|}{$1 \times C$ Df $(n-1)=9$} & 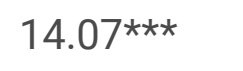 & $4.43^{\star}$ & $2.16^{\star \star \star}$ & $3.96 \star \star$ & $5.77 \star \star \star$ \\
\hline
\end{tabular}

*Significant at $p<0.05$ level, $* *$ Significant at $p<0.01$ level, $* * *$ Significant at $p<0.001$ level, means within column followed by same letters are not significantly $(p<0.05)$ different as determined by Duncan's Multiple Range

Table 5. Total flavonoid content in callus cultures of $D$. chinensis raised in different concentrations of 2, 4D supplemented MS medium 


\begin{tabular}{|c|c|c|c|c|c|c|}
\hline \multirow[t]{2}{*}{$\begin{array}{l}\text { Incubation } \\
\text { condition }\end{array}$} & \multirow{2}{*}{$\begin{array}{l}2,4-D \\
\text { Conc. } \\
(\mu \mathrm{M})\end{array}$} & \multicolumn{5}{|c|}{$\begin{array}{l}\text { Total flavonoid (mg QE g }{ }^{-1} \mathrm{DW} \text { ) estimated during different incubation } \\
\text { periods (days) }\end{array}$} \\
\hline & & 10 & 20 & 40 & 60 & 80 \\
\hline & 2.5 & $0.31 \pm 0.03^{b}$ & $0.49 \pm 0.09^{\mathrm{cd}}$ & $0.67 \pm 0.04^{e}$ & $0.77 \pm 0.05^{c}$ & $0.74 \pm 0.07^{d}$ \\
\hline \multirow[t]{5}{*}{ Light } & 5.0 & $0.32 \pm 0.02^{b}$ & $0.57 \pm 0.06^{c d}$ & $0.77 \pm 0.01^{\mathrm{e}}$ & $0.86 \pm 0.05^{c}$ & $0.79 \pm 0.01^{d}$ \\
\hline & 10 & $0.34 \pm 0.02^{b}$ & $0.75 \pm 0.07^{a}$ & $2.01 \pm 0.18^{b}$ & $3.85 \pm 0.24^{b}$ & $2.50 \pm 0.26^{b}$ \\
\hline & 15 & $0.34 \pm 0.03^{b}$ & $0.61 \pm 0.09^{b c}$ & $1.10 \pm 0.27^{\mathrm{cd}}$ & $2.82 \pm 0.77^{b}$ & $1.29 \pm 0.23^{c}$ \\
\hline & $\begin{array}{l}\text { Control } \\
\text { (0) }\end{array}$ & $0.18 \pm 0.02^{d}$ & $0.18 \pm 0.04^{f}$ & $0.20 \pm 0.03^{f}$ & $0.20 \pm 0.04^{d}$ & $0.21 \pm 0.02^{\mathrm{e}}$ \\
\hline & 2.5 & $0.32 \pm 0.02^{b}$ & $0.46 \pm 0.08^{d}$ & $0.84 \pm 0.05^{\text {de }}$ & $1.24 \pm 0.28^{c}$ & $1.13 \pm 0.03^{\mathrm{cd}}$ \\
\hline \multirow[t]{4}{*}{ Dark } & 5.0 & $0.37 \pm 0.04^{\mathrm{ab}}$ & $0.61 \pm 0.06^{b c}$ & $0.93 \pm 0.05^{\mathrm{de}}$ & $1.46 \pm 0.47^{c}$ & $1.51 \pm 0.09^{c}$ \\
\hline & 10 & $0.40 \pm 0.02^{\mathrm{a}}$ & $0.70 \pm 0.02^{a b}$ & $2.57 \pm 0.32^{\mathrm{a}}$ & $4.44 \pm 0.26^{\mathrm{a}}$ & $3.25 \pm 0.10^{\mathrm{a}}$ \\
\hline & 15 & $0.36 \pm 0.04^{\mathrm{ab}}$ & $0.60 \pm 0.02^{b c}$ & $1.28 \pm 0.13^{\mathrm{c}}$ & $3.02 \pm 0.30^{b}$ & $2.37 \pm 0.07^{b}$ \\
\hline & $\begin{array}{l}\text { Control } \\
(0)\end{array}$ & $0.21 \pm 0.02 c$ & $0.22 \pm 0.03 e$ & $0.23 \pm 0.03^{f}$ & $0.23 \pm 0.02^{d}$ & $0.27 \pm 0.05^{\mathrm{e}}$ \\
\hline \multicolumn{2}{|c|}{ Main effect Df $(n-1)=9$} & $3.21^{\star}$ & $6.54 * \star$ & $47.78 * \star \star$ & 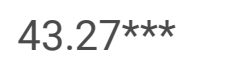 & $36.33^{\star \star \star}$ \\
\hline \multicolumn{2}{|c|}{$\begin{array}{l}\text { Incubation condition }(\mathrm{I}) \\
\operatorname{Df}(\mathrm{n}-1)=1\end{array}$} & $7.49 *$ & $3.22^{\star}$ & $15.07 * \star$ & $9.43 * \star$ & $47.93^{\star \star \star}$ \\
\hline \multicolumn{2}{|c|}{ 2,4-D conc. (C) Df (n-1)=4 } & $4.05^{\star}$ & $14.79 * \star$ & $104.43^{\star \star \star}$ & $97.45^{\star \star \star}$ & $67.08 * \star \star$ \\
\hline \multicolumn{2}{|c|}{$1 \times C$ Df $(n-1)=9$} & $0.95^{\mathrm{NS}}$ & $0.40^{N S}$ & $2.03^{N S}$ & $0.38^{\mathrm{NS}}$ & $1.72^{\mathrm{NS}}$ \\
\hline
\end{tabular}

*Significant at $p<0.05$ level, **Significant at $p<0.01$ level, ***Significant at $p<0.001$ level, NS at nonsignificant level, means within column followed by same letters are not significantly $(p<0.05)$ different as determined by Duncan's Multiple Range

\section{Figures}



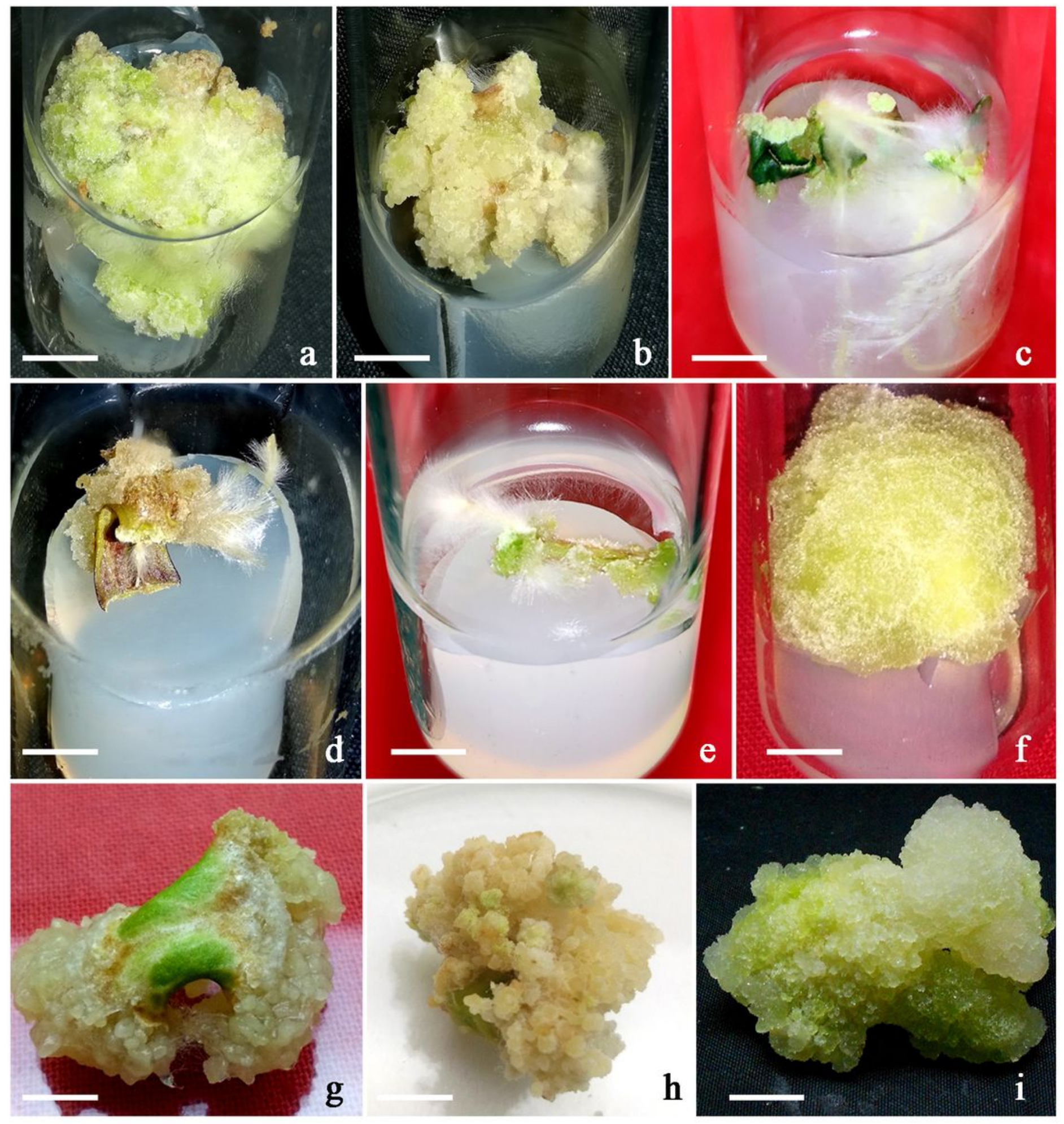

\section{Figure 1}

Effect of auxin types on callus induction in different explants of D. chinensis. (a) Friable callus induction from $2.5 \mu \mathrm{M}$ 2, 4- D (scale bar $0.7 \mathrm{~cm}$ ) or (b) picloram (scale bar $0.7 \mathrm{~cm}$ ); (c-e) root induction in $2.5 \mu \mathrm{M}$ NAA, IAA or IBA respectively (scale bar $0.6 \mathrm{~cm}$ ); (f) efficient callusing on $5 \mu \mathrm{M} \mathrm{2,4-D}$ (scale bar $0.6 \mathrm{~cm}$ ); $(\mathrm{g}$ and $\mathrm{h}$ ) nodular white calli from leaf explant (scale bar $0.4 \mathrm{~cm}$ ); (i) green calli from nodal explant after 1 week inoculation of $2.5 \mu \mathrm{M} 2$, 4- D supplemented MS medium (scale bar $0.4 \mathrm{~cm}$ ). 

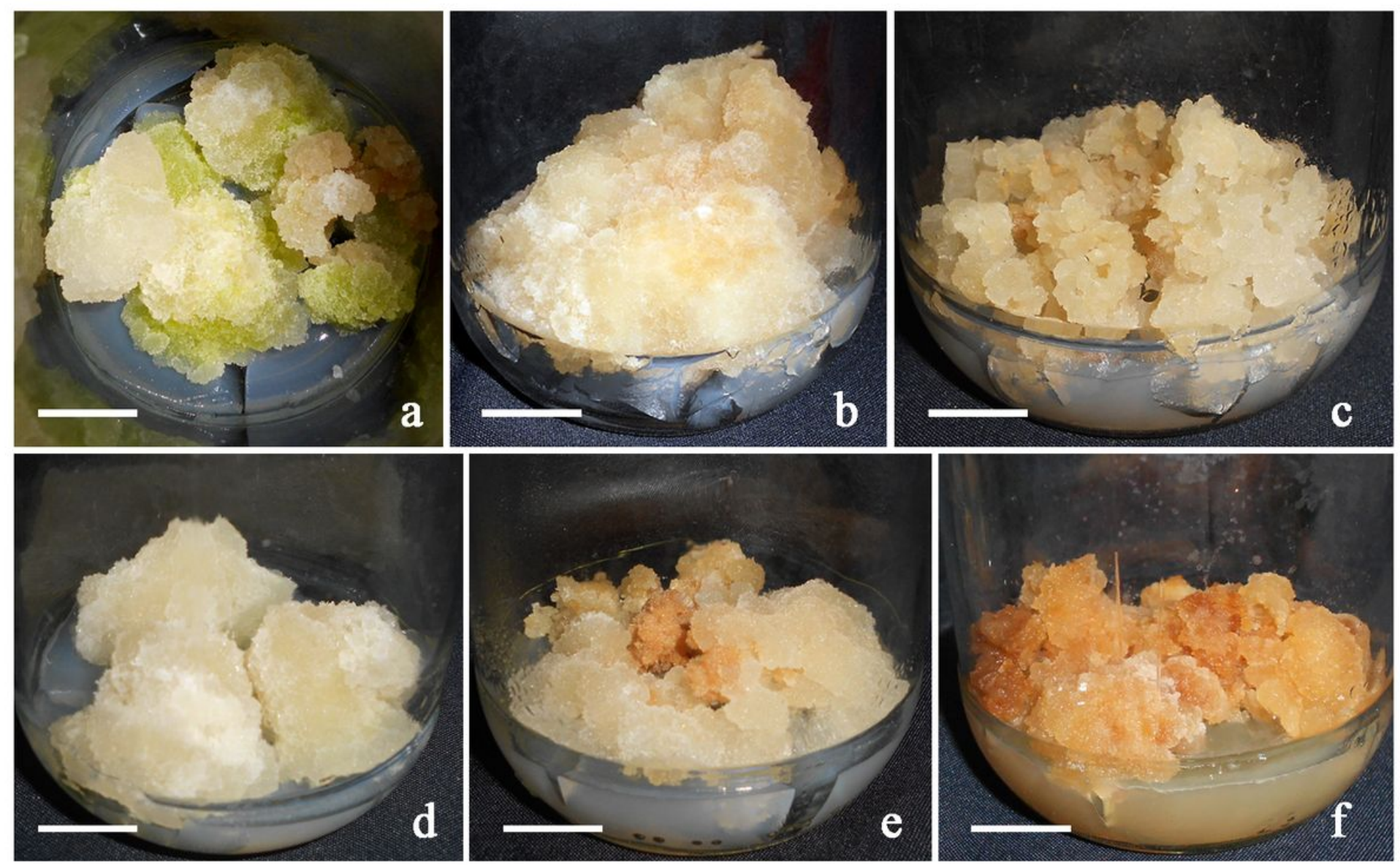

Figure 2

Callus production from different concentrations of auxins in D. chinensis. (a) Creamy green callus on 2,4$\mathrm{D}(5 \mu \mathrm{M})$ supplemented medium (scale bar $1.3 \mathrm{~cm})$; (b and c) high biomass accumulation from on $10 \mu \mathrm{M}$ or $15 \mu \mathrm{M} 2,4-\mathrm{D}$ at $16 \mathrm{~h}$ light condition (scale bar $1.2 \mathrm{~cm}$ ); and (d-f) white, creamy or yellowish brown callus after 40,60 , and 80 days of incubation in $10 \mu \mathrm{M} 2,4-\mathrm{D}$ at complete darkness respectively (scale bar $1.2 \mathrm{~cm})$. 

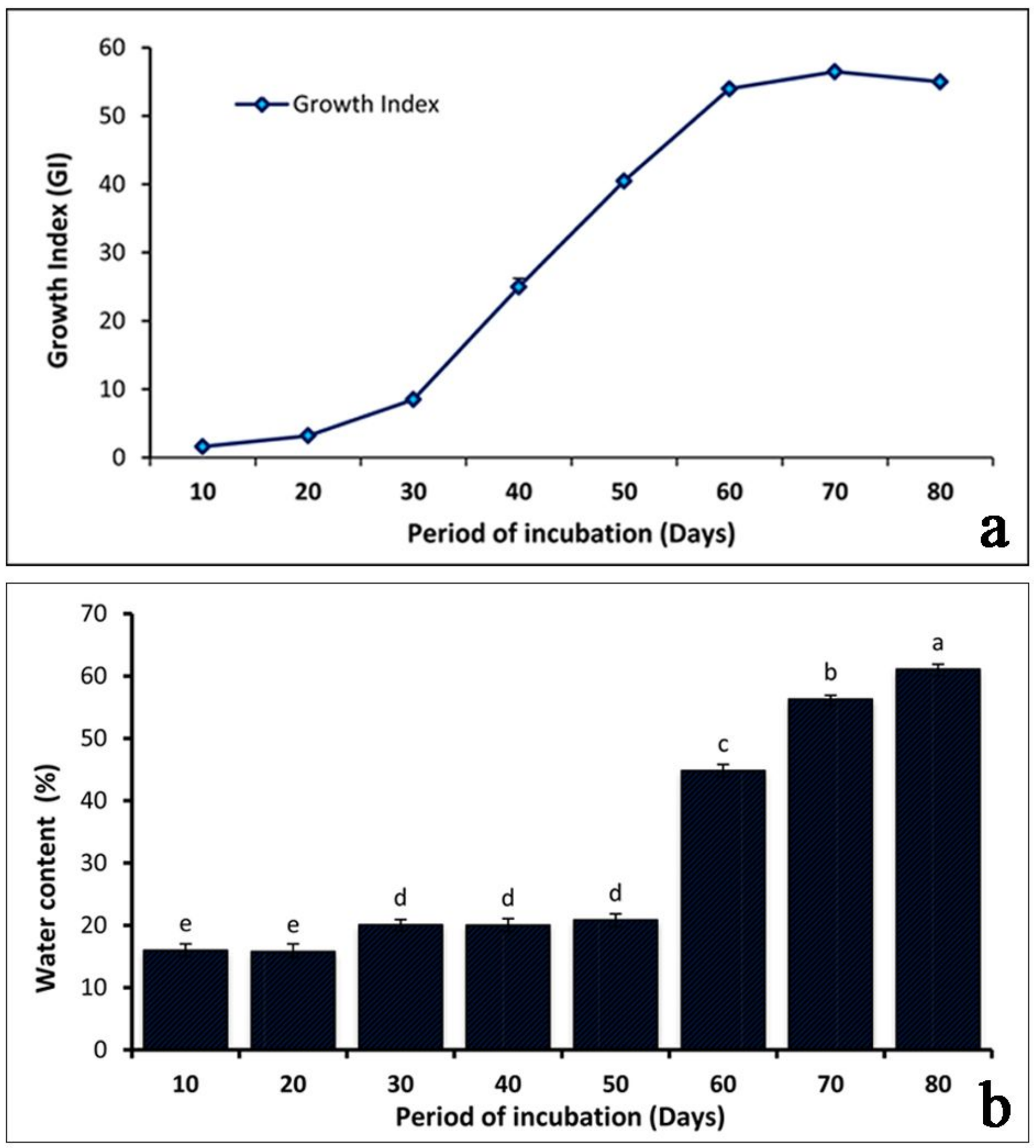

Figure 3

Growth index and water content analysis of callus culture of D. chinensis. (a) Growth index (GI); and (b) callus moisture content of callus cultures in $10 \mu \mathrm{M} 2,4-\mathrm{D}$ at $16 \mathrm{~h}$ - light/ $8 \mathrm{~h}$ dark condition. 


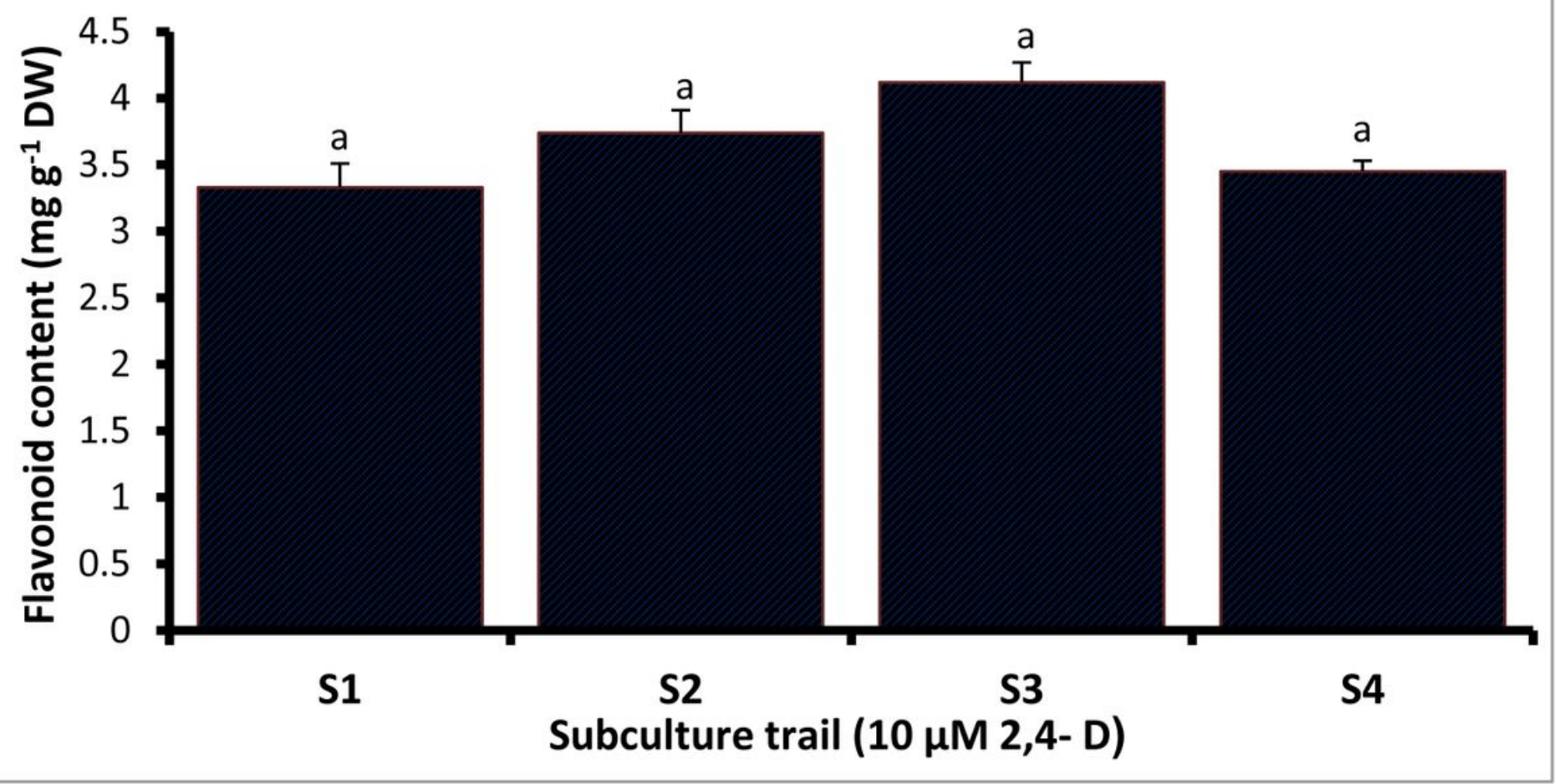

Figure 4

Stability of flavonoid production in $10 \mu \mathrm{M}$ 2, 4- D supplemented callus cultures of $D$. chinensis

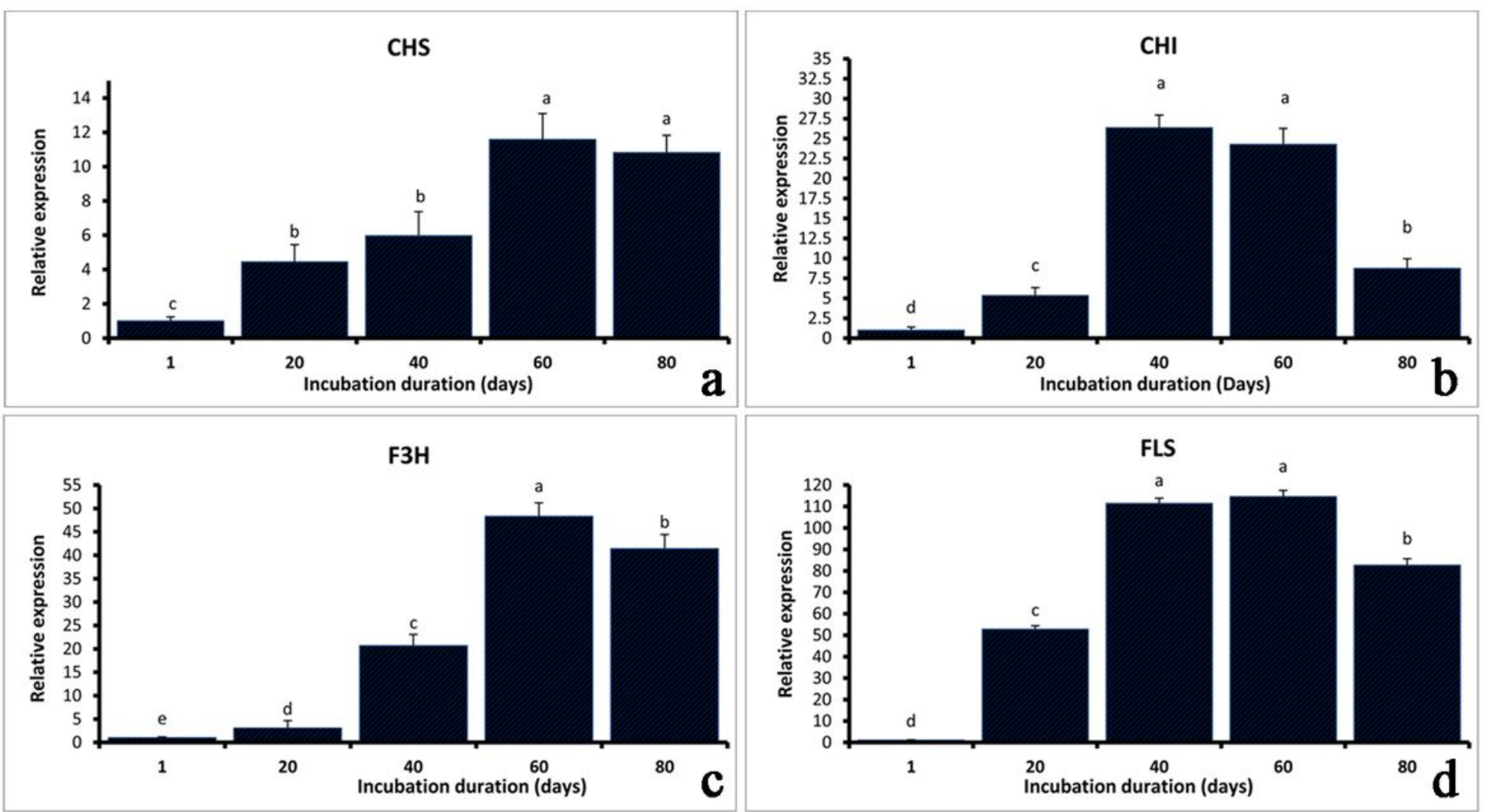

Figure 5 
Relative gene expression profile of flavonoid related genes a) $\mathrm{CHS}$; b) $\mathrm{CHI}, \mathrm{c}$ ) $\mathrm{F} 3 \mathrm{H}$; and d) FLS on callus tissues derived from 10 $\mathrm{MM}$ 2, 4- D (16 h light/ $8 \mathrm{~h}$ dark) at different time intervals (Day1, Day20, Day 40, Day 60 , or Day 80 ) 